\title{
SNOW MOLDS: HISTORY OF THE STUDY AND CONTROL (review)
}

\section{O.B. TKACHENKO ${ }^{1}$, A.V. OVSYANKINA ${ }^{2}$, A.G. SHCHUKOVSKAYA ${ }^{1}$}

${ }^{1}$ N.V. Tsitsin Main Botanical Garden, Russian Academy of Sciences, 4, ul. Botanicheskaya, Moscow, 127276 Russia, e-mail otkach@postman.ru;

${ }^{2}$ Russian State Agrarian Correspondence University, 1, ul. Fuchika, Balashikha, Moscow Province, 143900 Russia Received August 28, 2013

\section{Abstract}

Snow mold is caused by pathogenic low-temperature fungi and fungi-like pathogens which can attack grassy winter and perennial plants and even woody plants. Pathogens infect crops in autumn and develop under snow and early in spring at low temperatures. History of the emergence of the terminology for pathogenic low-temperature fungi, the appearance of the «snow mold» terms and domestic «vyprevaniye» (eng. «dumping-off») are represented, and various snow molds and their pathogens in Russia are described. Recent advances in agrochemical, chemical, biological and breeding technologies used to provide snow mold control are under consideration in detail, particularly data obtained in North America (USA, Canada), North Europe (Sweden, Norway, Finland), Asia (Japan) with special attention to the investigations in Russia. Crop rotation using crops being not the host plants of these pathogens and thus resistant to them is considered as rather effective agrotechnology decreasing plant damage from snow molds, and also deep tillage, early or late sowing, show thawing by its covering with black materials, monthly use of some composts are also discussed. Seed sterilization against Microdochium nivale infection is widely used in North Europe. In Russia the Baytan, Benlat, Granoza and Pentiuram are used on winter crops against Typhula incarnata and T. idahoensis (syn. T. ishikariensis). Fungicides are economically effective in the years of strong damage from snow molds, at that, pathogenic species differ in sensitiveness to fungicides. Characteristics of definite fungicides used are discussed. Biological suppression also is a method for anti-snow mold protection. For the purposes, the antagonistic agents effective in summer when snow molds are dormant, as well as low temperature agents active in the period of snow mold development can be used. Natural suppressors such as composts and antagonistic organisms were successful against Typhula spp. No special breeding for plant resistance to snow molds was carried out in Russia until recent time, nevertheless, in numerous investigations some grain crop species resistant to snow mold have been revealed. Particularly, by immunological assessment of 500 specimens from the VIR World Collection (N.I. Vavilov All-Russian Institute of Plant Industry, St. Petersburg) and domestic varieties the resistant forms are described as follows: Shatilovskaya tetra, Populyatsiya I-82 tetrs, Sibirskaya krupnozernaya, Taezhnaya, Kirovskaya 89, Vyatka 2, Dymka, Rosinka, Ilim, Falenskaya 4, Purga, F4-92, Chulpan 3, Korotkostebel'naya 6, Khar'kovskaya 88, Tatarskaya 1, Bezenchukskaya 88, Volkhova, Takovskaya 29; LAD-287 St-2614, Antonnisnie, Leelondzkie Kartowe № 1, Leelondzkie Krotnoslomix $\times$ Baltycnie (Poland), Epos, Rerus (DDR), Inzucht $74 / 2$, Inzucht 108/8 (Sweden), K-10953 (Finland), Feniks (Belgium), K-11385 (Yugoslavia), K11150, K-11389 (Portugal), K-11306 (Argentina), K-11179, к-11180 (USA), K-11388 (Tajikistan), K11398 (Georgia), K-11131 (Azerbaijan), Belta tetra (Belarus), Beve (Ukraine).

Keywords: low temperature fungi, snow molds, anti-snow mold agrotechnologies, chemical fungicides, biomethod, breeding for plant resistance to snow molds.

The snow mold is caused by pathogenic low-temperature fungal and fungi-like pathogens which attack overwintering plants [1, 2]. The lowtemperature fungi have been previously called psychrophilic (effectively grow at low temperatures) and psychrotrophic (affect plants at low temperatures, but can grow in mesophilic conditions). These definitions were suggested by R.Y. Morita [3] with regard to low-temperature bacteria. T. Hoshino and N. Matsumoto [4] have recently proposed a new term, «cryophilic fungi», because fungi are more complex organisms than bacteria, and their development cycle often comprises both mesophilic and psychrophilic stages. Show mold pathogens can attack not only grassy winter and perennial plants, but also woody plants, such as first-year pine seedlings [5] or the lower parts of tree branches under snow [6]. 
In the USSR, the term «damping-out» was used in snow mold studies [7-9]. This term was introduced in the 19th century, before the studies of lowtemperature fungi began [10], and it reflects physiological changes in plants, rather than the infectious nature of the disease [11, 12]. In the Soviet Union and Russia, only the disease caused by the fungus Fusarium nivale (Fr.) Ces. was called «snow mold» [13]. There are many names of the snow mold in the world scientific literature: pink snow mold caused by the fungus Microdochium nivale (Fr.) Samuels \& Hallett [syn. Fusarium nivale (Fr.) Ces.] [14-16]; gray snow mold, caused by Typhula incarnata Lasch. ex Fr. [17, 18]; speckled (or gray) snow mold caused by the fungus $T$. ishikariensis $\mathrm{S}$. Imai [17, 19, 20]; sclerotial snow mold, caused by fungus Sclerotinia borealis Bubak \& Vleugel [syn. Myriosclerotinia borealis (Bubak \& Vleugel) Kohn, S. grami-nearum Elenev et Solkina], often called «snow scald» or «snow blight» [21, 22]; as-yetunnamed, relatively recently described snow mold caused by the fungus $S$. nivalis I. Saito (23]; Pythium snow mold, caused by fungi-like Oomycetes Pythium spp. (P. iwayamai S. Ito, P. okanoganense P.E. Lipps and P. paddicum L.) [24-26], etc.

It is hard to control the snow mold because pathogens usually infect crops in autumn and develop under snow and early in spring at low temperatures. Plant spraying with fungicides is difficult or impossible in this period. Various snow mold forms are favored by the thick snow cover and prolonged spring. Plant freezing provokes the growth of the sclerotial snow mold caused by the necrotroph $S$. borealis. Conversely, non-frozen soil promotes the damage by the biotroph $T$. ishikariensis. Therefore, the sclerotial snow mold prevails in the areas where plants are subject to freezing (Volga Region, Urals, Siberia) [27]. However, Novosibirsk populations of the fungus T. ishikariensis are much more adapted to freezing than Moscow strains [28]. In addition, it is difficult to predict winter conditions; explosive development of the snow mold is a quite rare phenomenon, and the cost of protective measures is high.

The snow mold is controlled using agrotechnical, chemical and biological methods. Another way to reduce damage by the snow mold is selection of snow mold-resistant plants.

Agrotechnical method. In rye cultivation, the crop rotation and deep ploughing reduce the $S$. borealis inoculum quantity within the field $[5,29]$ but do not provide efficient control of the fungus because airborne ascospores are mainly transferred from uncultivated lands, such as meadows.

Placement of solar-absorbing black materials on snow promotes thawing and makes it possible to reduce damage from the snow mold. Thus, it was V.V. Gulyayev who recommended to deliberately get rid of snow in late spring with prolonged thawing (especially in depressed areas) by dispersing fragmented peat or ash over the surface [5]. Many authors [30-32] have studied the influence of graphite and carbon powder on acceleration of snow thawing. Mechanical removal of snow is impractical [33] and may increase the damage of plants due to their high sensitivity to frosts in early spring after snow removal [34].

Crop rotation and deep ploughing are key measures to reduce the number of sclerotia in soils. Such agronomic practice contributes to minimization of the forage legume damage caused by $S$. trifoliorum and $S$. sativa on overwintering dicotyledonous crops $[35,36]$.

Due to early sowing of the winter wheat in autumn, stronger plants can better sustain an attack by the speckled snow mold than small ones in case of later planting [22, 34, 37]. The fields sown very late sometimes avoid getting infected, but once infected, plants perish [34]. Early planting leads to destruction of leaves by the snow mold, however, in general, the plant grows again from the tillering node and recovers. Field trials and experiments in climatic chambers $[38,39]$ confirm that larger plants survive better such snow molds as speckled 
and pink ones, but the larger the plant, the greater is the number of sclerotia on it, which leads to greater infection load on soil.

Although snow mold growth is significantly influenced by the seeding time, it does not depend on other agricultural practices (tillage, equipment, seeding depth) in this period [34, 37, 39].

Nitrogen fertilization has the greatest effect on the pathogenic process. Nitrogen application on lawn grasses leads to increased growth of the snow mold [40]. Additional fertilization with some composts on a monthly basis is efficient with regard to containment of a wide range of diseases, including the snow mold caused by the fungi Typhula spp. and Microdochium nivale [41].

In case of rotation with the crops that are not referred to host plants for snow mold pathogens, snow mold growth decreases. The winter wheat cultivated in the field where spring wheat has been under cultivation for several years is affected by the fungus $T$. idahoensis in a lesser extent than in case if seeding after winter wheat [31]. After the medick, the number of $T$. idahoensis sclerotia was greater than after winter wheat [42]. Whereas the wheat seeded after leguminous plants (medick, white sweet-clover or pea) demonstrated insignificant damage by the snow mold, the extent of such damage increased with every subsequent winter wheat seeding [37].

Chemical method. Grain sterilization against the snow mold [43, 44] has been tested and is widely used to control the Fusarium seed infection caused by $M$. nivale in North Europe [45]. In Russia, it was recommended to treat winter grain crops [ $T$. incarnata and $T$. idahoensis (syn. T. ishikariensis)] with Baitan Universal, Baitan, Benlate (Fundazol), Granozan and Pentiuram [46] against the Typhula blight, although the recommendation on sterilization using benzimidazole chemicals, such as Benomyl, Fundazol, etc., against the Typhula spp. causes doubt. Efficiency of fungicides against various species of snow mold pathogens is different, and, in some cases, such treatment may even stimulate the snow mold growth. For example, the extent of affection by the fungi of the genus Typhula increases in case of treatment with Benomyl [47, 48], Cercobin M, Bavistin [49]. Stronger progression of the Typhula blight in case of Benomyl is associated with mycelium growth stimulation [50] and suppression of antagonistic mycobiota [51]. Typhula blight affection may also increase in case of treatment with other pesticides, such as insecticide Dimetalan [52].

In the middle of the $20^{\text {th }}$ century, mercurial and many other fungicides, which are now prohibited for environmental reasons, were used for snow mold control $[53,54]$. A negative aspect is that mercurial pesticides are not decomposed into non-toxic components; instead, they persist in soil, for example, on golf courses [55], and may contaminate adjacent aquatic ecosystems [56]. Use of mercury compounds in fungicides is prohibited in Russia [57].

There is an opinion that field crop spraying against the snow mold is not cost-effective in general [33]. Although fungicide can efficiently protect grain crops $[44,47,58]$, epiphytoties are sporadic, and it is impossible to determine in advance if treatment is needed. Spraying with fungicides is economically feasible in years with severe damage, when substantial benefits can be obtained (for example, increase in yield, product quality improvement or stable income). As a result, the majority of papers on fungicide application discuss studies on grass plots, especially on golf courses, due to their high cost $[59,60]$.

In northern Japan, as reported by I. Saito et al. [61], fungicide spraying on leaves early in winter is a mandatory practice in wheat cultivation because the snow mold reduces wheat yield. On wheat fields, $S$. borealis is usually encountered in combination with one or more pathogens causing the snow mold, for example, $T$. ishikariensis or $M$. nivale. Therefore, a need arises for a fungicide which is effective against all these pathogens, or a mixture of fungicides. 
On Hokkaido, where the winter wheat is cultivated more extensively than elsewhere in Japan, the following active substances of fungicides are recommended for snow mold control: Fluazinam against $S$. borealis, $T$. ishikariensis, $T$. incarnata and $M$. nivale, Benomyl against $S$. borealis, Thiophanate-methyl against $S$. borealis, Iminoctadine Triacetate against $S$. borealis and $M$. nivale.

In Canada, before formation of snow cover, the snow mold is controlled by spraying of fungicides with the following active substances: Chloroneb, Chlorotalonyl, Iprodione, Propiconazole and Quintozene [62].

In the USA, a list of allowed chemicals (by active ingredients) against the snow mold is wider: Azoxystrobin, Chloroneb, Chloroneb + Thiophanatemethyl, Chlorotalonyl + Fenarimol, Chlorotalonyl + Thiophanate-Methyl, Cyproconazole, Fenarimol, Flutolanyl, Iprodione, PCNB (penta-chloronitrobenzene), Propiconazole, Tiram, Triadimefon, Vinclozolin [63].

At present, in the Russian Federation, in accordance with the list of fungicides allowed for use in 2014 [57], fungicides with the following active substances may be applied: Azoxystrobin, Iprodione, Propiconazole, Tiram, Triadimefon, Fenarimol, Chlorotalonyl, Cyproconazole (it should be noted that there are no recommendations on their use on lawn grasses and winter grain crops against the snow mold). With regard to the snow mold (including the Typhula one), it is advised to perform preplanting treatment of winter rye grains with preparations with the following active substances: Carbendazim, the preparations Kolfugo Super, SC (suspension concentrate), Kolfugo Super Color, SC (AgroChemie Kft., Hungary); Ferazim, SC (LLC Agro Expert Group, Russia); Karbonar, SC (LLC Agrobyuro RUS, Russia); Carbendazim + Carboxin, the preparation Kolfugo Duplet, SC (Agro-Chemie Kft., Hungary); complex mixture: Klotianidin + Fluoxastrobin + Prothioconazole + Tebuconazole, the preparation Scenic Combi, SC (Bayer CropScience AG, Germany).

It is reported about the Terminator preparation with the same active substances as in Kolfugo Duplet [64], however, it is not included in the list of pesticides allowed for use in the Russian Federation [57].

There are no registered fungicides against the sclerotial snow mold of the rye $(S$. borealis) in Russia. According the data of All-Russian Research Institute of Plant Protection (St. Petersburg) [64], this disease is especially common in the Central and Volga-Vyatka Regions where crop losses achieve 20-25\%.

Fungicide testing has shown that the most efficient protection of grasses and winter grain crops against the gray snow mold ( $T$. ishikariensis) is provided by spraying the plant leaf surface, before formation of perennial snow cover, with preparations Alto $(0.2 \mathrm{l} / \mathrm{ha})$, Alto Super $(0.4 \mathrm{l} / \mathrm{ha})$ (Syngenta AG, Switzerland), or combination of the above treatments with preplanting treatment of seeds with preparations Dividend Star (2 l/t) and Dividend Total (2 1/t) (Syngenta AG, Switzerland) [65]. Sterilization of winter grain crop seeds against the gray snow mold alone is not efficient, but, taking into account the protective action of these treaters against root rots, it is reasonable to combine seed sterilization with ground treatment using proved fungicides [65]. In field conditions, the best protection of winter grain crops against the snow mold (M. nivale and $T$. ishikariensis) was provided by crop spraying with Alto Super and Tilt at rate of $0.5 \mathrm{l} / \mathrm{ha}$ before formation of snow cover. Biological efficiency of application of these preparations was $96.1 \%$ and $93.1 \%$, respectively. It has been found [66] that plant treatment with growth regulators Obereg (LLC Orton, Russia) and Silk (CJSC Elkha-Silk and Sayany-Elkha, Russia) delays plant infection by the fungus $T$. ishikariensis by 30 days; in case of fungicide Alto Super, the delay is within 75-90 days, depending on snow cover thickness and longevity. The protective action of Alto Super was observed within 75-90 days under weather conditions favorable for Typhula blight development and 90-105 days under less fa- 
vorable conditions. When seed treatment with preparation Maxim was combined with autumn spraying with Alto Super, wheat plants were better than the control during the vegetation period with regard to physiological parameters (chlorophyll content, water-retaining capacity, dry weight of plants) and, ultimately, with regard to the yield which was higher by 70-80\% than that of the control plants. Biological efficiency of autumn treatment of winter crops with Alto Super $(0.5 \mathrm{l} / \mathrm{ha})$ was $80-90 \%$ and did not depend on the seed treaters applied. It is notable that even the half-rate $(0.25 \mathrm{l} / \mathrm{ha})$ was efficient in conditions of moderate development of the Typhula blight. In a study on 10 species of lawn grasses [67], eight species of the genus Fusarium Link, including $M$. nivale, have been considered as pink snow mold pathogens. It has been found that fungicide Bravo, SC (active substance-Chlorotalonyl, $500 \mathrm{~g} / \mathrm{l}$ ) was efficient in case of autumn spraying at rate of $2.0 \mathrm{l} / \mathrm{ha}$ for grass stands of the English ryegrass and red fescue. In 2010-2011, this preparation reduced pink snow mold development by a factor of 2-4 as compared with reference preparation Quadris, SC (Azoxystrobin, $250 \mathrm{~g} / \mathrm{l}$, as an active substance).

Because it is difficult to forecast weather conditions, multiple treatments are often required instead of one. New active substances and formulas are brought to the market from time to time; however, protection against the snow mold using fungicides requires an alternative [68].

Biological method. In development of a biological method, it is necessary to begin with the study of relationships between organisms [69]. In case of low-temperature forms, antagonists may be represented by both mesophylls during the aestivation of snow mold pathogens (sclerotia), and lowtemperature bioagents active in the course of pathogen development [70].

Both natural suppressors, such as composts, and antagonistic organisms were successfully used against the snow mold caused by Typhula spp. in a number of studies.

Monthly application of relatively small amounts of suppressive composts $\left(5 \mathrm{~kg} / 100 \mathrm{~m}^{2}\right)$ during the vegetation period can suppress many lawn grass diseases, including the snow mold caused by the fungi of genus Typhula [71, 72]. Also, shocking doses $\left(100 \mathrm{~kg} / 100 \mathrm{~m}^{2}\right)$ of some composts are efficient when applied on golf courses in late autumn. The main problem associated with the use of suppressive composts is their variable efficiency by years and plots [73].

The influence of 164 bacterial isolates in seed treatment against the root rot caused by Fusarium culmorum and the snow mold pathogen M. nivale has been investigated in Sweden. The performance of three Pseudomonas fluorescens and one isolate of the genus Pantoea (isolate MF 626) has been noted: they were as efficient as fungicide Guazatine [74]. The experiments aimed at comparing seed treatment and spaying with the bacterium Pseudomonas brassicacearum (strain $\mathrm{MA}_{250}$ ) during planting have demonstrated some efficiency, with a less noticeable effect in case of spraying [75].

Biofungicide Elena $\mathrm{Zh}$ applied on winter wheat Bezenchukskaya is biologically efficient against the snow mold at the level of chemical fungicide Ferazim, SC; also, it exhibits growth-stimulating properties, which allows it to ensure high yield of grain crops even in severe weather conditions (drought) [76].

Some species of the genus Trichoderma are antagonists of summer sclerotia of $T$. incarnata and can reduce the inoculum potential of the gray snow mold pathogen. The viability of sclerotia significantly decreased after incubation with Trichoderma cultures within 6 days [77].

It has been found [78] that in summer in field conditions over $90 \%$ of the sclerotia of $T$. incarnata are naturally killed by mycoparasites, whereas the sclerotia of $T$. ishikariensis of biotype A mainly survive. The mycoparasites $\mathrm{Co}$ - 
niothyrium minitans Campbell, Gliocladium roseum Bain. and Trichoderma spp. were extracted from the sclerotia of $T$. incarnata. All of them also parasitized T. ishikariensis of biotype A in laboratory conditions. However, a practical result was not achieved because even several survived sclerotia in autumn may lead to spread of the pathogen with basidiospores, and field treatment of the sclerotia of $T$. ishikariensis of biotype A with mycoparasites is very difficult during the plant vegetation period.

Attempts to use bacteria as antagonistic organisms have not led to noteworthy results, although the pseudomonas fluorescens isolates antagonistic to $T y$ phula incarnata and T. ishikariensis of biotypes A, B, and C have been revealed [78-80]. In addition, two strains of Bacillus sp. with similar properties have been isolated [80].

At first, Typhula phacorrhiza was considered as a pathogen previously not observed on lawns, but it also turned out that this species was not pathogenic on the creeping bent in field trials with inoculation. Conversely, the fungus suppressed the gray snow mold development [81-83]. In Japan, a similar fungus, T. phacorrhiza, suppressed the snow mold on the English ryegrass [84]. In Canada, the T. phacorrhiza isolates extracted from wheat residues had different capability of suppressing the gray snow mold in field trials within more than 3 years $[85,86]$. The efficiency of more than 29 isolates of $T$. phacorrhiza has been screened on 14 plant species against $T$. ishikariensis and T. incarnata [87, 88], and the most active strain TP94671 has been identified. No strong correlation between laboratory and field trial data was noted in T. phacorrhiza isolate tests [89], therefore the laboratory results cannot serve as preliminary data for selection of antagonistic strains [89]. Gray snow mold forcing-out from fields is obviously promoted by high capacity for utilization of structural and reserve carbohydrates in combination with a wider optimum temperature range in case of $T$. phacorrhiza as compared with pathogenic $T$. ishikariensis and T. incarnata [90].

One possible problem associated with the use of $T$. phacorrhiza as a bioagent is its potential pathogenicity. Some isolates of $T$. phacorrhiza were pathogenic on wheat under controlled environment conditions and field conditions [91, 92]. In other field trials, the isolates of $T$. phacorrhiza were not pathogenic with regard to a number of lawn grass species [89].

In Russia, T. phacorrhiza was first applied for control of the most aggressive speckled snow mold (caused by T. ishikariensis) by S.V. Tazina [93]. The autumn application of the fungus $T$. phacorrhiza on winter wheat crops with the $T$. ishikariensis infection background led to less damage by the speckled snow mold in spring. Biological efficiency of winter grain crop protection using the fungus $T$. phacorrhiza $\left(200 \mathrm{~g} / \mathrm{m}^{2}\right)$ was $75.2 \%$, which is by $30.3 \%$ and $17.6 \%$ higher than after treatment with Fundazol and Bayleton, respectively.

A psychrotolerant hyperparasite, Trichoderma atroviride P. Karst, has been found in the subarctic areas of Alaska. It has been revealed that it suppressed the development of the wide range of snow mold pathogens: Coprinus psychromorbidus, Microdochium nivale, Myriosclerotinia (Sclerotinia) borealis, Pythium spp., Typhula incarnata, T. idahoensis and T. ishikariensis (biological species 1 according to N. Matsumoto et al.) [94-98]. T. atroviride is a mesophyll which is well adapted to cold conditions. Its temperature range is from $4{ }^{\circ} \mathrm{C}$ (or lower) to $33{ }^{\circ} \mathrm{C}$, which makes it possible to use it for control of the phytopathogens causing damage to the roots, stems and other organs of plants in cold conditions when plant tissues are vulnerable. T. atroviride rapidly grows and produces large quantity of spores. Isolate CHS 861 of $T$. atroviride is naturally resistant to Metalaxyl (Ridomil), Captan and PCNB (Terrachlor) [95]. T. atroviride 
can use snow molds as a feed source. The hyphae of the fungus easily penetrate cell walls and interweave with the hyphae of the snow mold pathogen. The cells disintegrate and are rapidly lysed. The chitin-lytic enzymes produced by $T$. atroviride obviously play an important role in mycoparasitism on snow mold pathogens [96].

Other organisms that can suppress the snow mold pathogen growth, such as the fungus Actemonium boreale described by J.D Smith \& J.G.N. Davidson [99] in Canada, have been identified as well. It is also antagonistic with regard to other snow mold pathogens and exhibits slight parasitic properties on two grass species, however, it is unable to suppress $M$. nivale and low temperature basidiomycete (LTB) in trials under controlled conditions [100].

The studies of the winter wheat nematofauna in pink snow mold niduses [101-104] have resulted in identification of several species of low-temperature mycotrophic nematodes (Aphelenchoides saprophillus Franklin, Paraphelenchus tritici Baranovskaya, Aphelenchus avenae Bastian) consuming pink snow mold pathogen $M$. nivale. Among the mycohelminth species added into test tubes with the mycelium of the fungus $M$. nivale, the most intensive development was observed for $A$. saprophillus. At $5{ }^{\circ} \mathrm{C}$ this species destroyed the fungus mycelium within 60-70 days after adding into the test tube, its number being 1,208 specimens per test tube. In the presence of $P$. tritici or A. avenae, after 60-70 days, the fungus mycelium was only on $40-50 \%$ of the surface of the growth medium. The number of nematodes was significantly less than in test tubes with A. saprophillus. A microplot field trial with application of the mycohelminth A. saprophillus (160,000 specimens, 80,000 specimens and 38,000 specimens) on the winter wheat crops infected by the pink snow has shown that biological efficiency was $62.7 \%, 52.7 \%$ and $43.1 \%$, respectively. In the first case, the efficiency was by $6.7 \%$ and $45.3 \%$ higher than in the second and third ones, respectively. Nematodes had no influence on economic efficiency (yield), but they substantially reduced the degree of disease development and improved the productive qualities of plants. Thus, mycohelminths capable of multiplication at low temperatures may be used as potential bioagents in order to control the pink snow mold of the winter wheat, and it can be conceived that the most efficient bioagent against the pink snow mold pathogen is the mycohelminth A. saprophillus which significantly limits the population of the low-temperature fungus in the autumn-winter-spring period.

Selection method. Resistance to snow molds has been studied, first of all, for economically significant cultivated plants, such as winter grain crops. The history of selection works aimed at breeding the snow mold resistant varieties of these crops in North America, North-European countries and Japan has been already presented in details [105]. In Russia, targeted studies related to selection by resistance to snow molds have not been carried out, obviously, because it is impossible to use the climatic chambers capable of creating nearwinter conditions, as was done in the USA [106, 107] and Japan [108], and also by the reason that epiphytoties of the most harmful snow mold pathogen in Russia, Typhula ishikariensis, are quite seldom.

Nevertheless, a number of investigations aimed at identifying grain crop species resistant to various snow mold species have been carried out in Russia. Particularly, against the infection background, an immunological assessment of 500 variety specimens from the VIR World Collection (N.I. Vavilov All-Russian Institute of Plant Industry, St. Petersburg) and domestic varieties has been made by damping-out percentage and intensity of leaf surface damage, and the following resistant specimens have been selected: the domestic varieties such as Shatilovskaya tetra, Populyatsiya I-82 tetra, Sibirskaya krupnozernistaya, Taezhnaya, Kirovskaya 89, Vyatka 2, Dymka, Rosinka, Ilim, Falenskaya 4, Purga, F4-92, 
Chulpan 3, Korotkostebelnaya 6, Kharkovskaya 88, Tatarskaya 1, Bezenchukskaya 88 , Volkhova, Talovskaya 29; the variety specimens from the VIR World Collection such as LAD-287 St-2614, Antonnisnie, Leelondzkie Kartowe № 1, Leelondzkie Krotnoslomix Baltycnie (Poland), Epos, Rerus (DDR), Inzucht 74/2, Inzucht 108/8 (Sweden), k-10953 (Finland), Feniks (Belgium), k-11385 (Yugoslavia), k-11150, k-11389 (Portugal), k-11306 (Argentina), k-11179, k-11180 (USA), k-11388 (Tajikistan), k-11398 (Georgia), k-11131 (Azerbaijan), Belta tetra (Belarus), Beve (Ukraine) [109].

There is an opinion that, besides Triticum aestivum, closely-related genera, such as Secale, Aegilops, Haynaldia and Agropyron, may have the germ plasm sources for improving wheat survival in winter, and it is assumed that Ae. cylindrica can be a new source of heritable resistance to the snow mold [110, 111]. This idea has been confirmed [93]. Among proved winter wheat varieties and hybrids against the infection background of T. ishikariensis and M. nivale [93], the best resistance to pathogens has been demonstrated by hybrids PPG224 (wheat-agropyron hybrid) and PEG-149 (wheat-elymus hybrid). Based on chemical mutagenesis, a promising winter wheat variety, Imeni Rappoporta, has been obtained from PPG-186 [112, 113]. This variety surpassed reference varieties Mironovskaya 808, Zarya and Moskovskaya 39 in many parameters, including snow mold resistance.

It should be noted that Russian varieties and lines often turned out to be more resistant than foreign specimens in spite of the lack of targeted selection against snow molds. For example, a specimen from Russia, which is called Dormie (Sonya) by authors [114], has demonstrated much more resistance to the cottony snow mold pathogen (LTB, not encountered in Russia) in Canada, and variety Valuyevskaya is a standard of resistance to low temperatures (often associated with snow mold lesion) in Western countries.

Thus, it is difficult to control the snow mold because the pathogens usually infect crops in autumn and develop under snow and early in spring at low temperatures. There are different ways to control snow molds: agrochemical, chemical, biological and breeding methods. Corresponding developments are underway in all directions; however, selection for resistance continues to be a key strategy. In this regard, the progress is associated with identification of the genetic factors controlling the resistance, as well as with improvement of techniques for acceleration of stable line selection. The biological method is being actively developed, in particular, in Russia, where, besides fungal and bacterial organisms, a new bioagent, mycotrophic nematode, has been used for the first time.

\section{REFEREN C ES}

1. Matsumoto N. Snow molds: a group of fungi that prevail under snow. Minireview. Microbes Environ., 2009, 24(1): 14-20 (doi: 10.1264/jsme2.ME09101).

2. Hoshino T., Xiao N., Tkachenko O.B. Cold adaptation in phytopathogenic fungi causing snow molds. Mycoscience, 2009, 50(1): 26-38 (doi: 10.1007/S10267-008-0452-2).

3. M o rit a R.Y. Psychrophilic bacteria. Bacteriol. Rev., 1975, 39: 144-167.

4. Hoshino T., Matsumoto N. Cryophilic fungi to denote in the cryosphere. Fungal Biology Reviews, 2012, 26(2-3): 102-105 (doi: 10.1016/j.fbr.2012.08.003).

5. G u l y a e v V.V. Trudy Tatarskoi lesnoi opytnoi stantsii (Kazan'), 1948, 9: 44-49.

6. Ku z' $\mathrm{m}$ in a N.A., Ku z' m i n S.R. Khvoinye boreal'noi zony, 2007, XXIV(4-5): 454-460.

7. Tumanov I.I., Borodina I.N., Oleinikova T.V. Trudy po prikladnoi botanike, genetike, selektsii, 1935, 3(6): 3-57.

8. Tupenevich S.M. Trudy Vsesoyuznogo nauchno-issledovatel'skogo instituta zashchity rastenii, 1966, 28: 126-130.

9. K u p e r m a n F.M., M o i s e i c hi k V.A. Vyprevanie ozimykh kul'tur [The «dumping-off» in winter crops]. Moscow-St. Petersburg, 1977.

10. Dan'kova T.N. Russkaya sel'skokhozyaistvennaya terminologiya kontsa $X X$-nachala $X X I$ $V V$. (na materiale terminologii rastenievodstva) [Russian agricultural terminology from the end of XX to the beginning of XXI century in plant industry]. Voronezh, 2009. 
11. N e d o lu z h k o A.I. Vestnik DVO RAN, 2004, 4: 74-77.

12. Shelepova O.V., Voronkova T.V., Kondrat'eva V.V., Danilina N.N. Fiziologiya i biokhimiya kul'turnykh rastenii, 2009, 41(5): 384-392.

13. Tupe nevich S.M. V sbornike: Izvestiya vysshikh kursov po prikladnoi zoologii $i$ fitopatologii [In: Proceedings of the Highest Courses on applied zoology and phytopathology]. Leningrad, 1940, 10: 5-108.

14. Hoshino T., Ohgiya S., Shimanuki T., Ishizaki K. Production of low temperature active lipase from the pink snow molds, Microdochium nivale (syn. Fusarium nivale). Biotechnology Letters, 1996, 18(5): 509-510.

15. N a k a ji m a T., A b e J. Environmental factors affecting expression of resistance to pink snow mold caused by Microdochium nivale in winter wheat. Can. J. Bot., 1996, 74(11): 1783-1788 (doi: 10.1139/b96-215).

16. Iriki N., Nakajima T., Kawakami A. Reaction of winter wheat cultivars to artificially inoculated seed-born pink snow mold. Breeding Science, 1992, 52(3): 231-233 (doi: $10.1270 /$ jsbbs.52.231).

17. Hsiang T., Matsumoto N., Millett S.M. Biology and management of typhula snow mold of turfgrass. Plant Disease, 1999, 83(9): 788-798 (doi: 10.1094/PDIS.1999.83.9.788).

18. Vergara G.V., Bughrara S.S., Jung G. Genetic variability of grey snow mould (Typhula incarnata). Mycological Research, 2004, 108(11): 1283-1290.

19. S mith J.D. Snow molds of winter cereals: guide for diagnosis, culture, and pathogenicity. Can. J. Plant Pathol., 1981, 3(1): 15-25 (doi: 10.1080/07060668109501398).

20. G a u d e t D.A., B h a 11 a M.K. Survey for snow mold diseases of winter cereals in central and northern Alberta. Can. Plant Dis. Surv., 1988, 68(1): 15-18.

21. Groves J.W., B ow e rm a n C.A. Sclerotinia borealis in Canada. Can. J. Bot., 1955, 33: 591-594.

22. To mi y a m a K. Studies on the snow blight disease of winter cereals. Rep. Hokkaido Agric. Exp. Stn., 1955, 47(1): 1-234 (in Japanese with English summary).

23. S a i to I. Sclerotinia nivalis, sp. nov., the pathogen of snow mold of herbaceous dicots in Northern Japan. Mycoscience, 1997, 38: 227-236 (doi: 10.1007/BF02460857).

24. Lips P.E. A new species of Pythium isolated from wheat beneath snow in Washington. Mycologia, 1980, 72(6): 1127-1133 (doi: 10.2307/3759566).

25. Li ps P.E., B ru e hl G.W. Infectivity of Pythium spp. in snow rot of wheat. Phytopathology, 1980, 70: 723-726.

26. Take naka S., Arai M. Dynamics of three snow mold pathogens Pythium paddicum, Pythium iwayamai, and Typhula incarnata in barley plant tissues. Can. J. Bot., 1993, 71: 757-763 (doi: 10.1139/b93-087).

27. T k a c h e n k o O.B. Byulleten' Glavnogo botanicheskogo sada (Moscow), 2012, 198(4): 63-70.

28. Hoshino T., Tkachenko O.B., Tronsmo A.M., Kawakami A., Morita N., $\mathrm{Ohg}$ i y S., Ishizaki K. Temperature sensitivity and freezing resistance among isolates of Typhula ishikariensis from Russia. Būvisindi, Icel. Agr. Sci., 2001, 14: 61-65.

29. Khokhryakov M. Maloizvestnaya bolezn' ozimykh khlebov (sklerotiniya). Zashchita rastenii, 1935, 4: 94-97.

30. Fish e r W.R., B rue hl G.W. Efficacy of various blackening agents in hastening snow melt, a possible tool in snow mold control. Phytopathology, 1964, 54(12): 1432.

31. Bruehl G.W., Sprague R., Fischer W.R., Nagamitsu M., Nelson W.L., Voge 1 O.A. Snow molds of winter wheat in Washington. Washington Agric. Exp. Stn. Bull., 1966, 677: 1-21.

32. Kotte r C.M. Ash speeds melt to aid grain growers. Western Hay and Grain Grower, 1979, January: 4-6.

33. G o s s e n B.D., H si a n g T., M u r ray T.D. Managing snow mold disease of winter cereals and turf. Plant-microbe interactions at low temperature under snow. Chapter 2. Sapporo, Hokkaido National Agricultural Experiment Station, 2001: 13-21.

34. Holst o n C.S. Observation and experiments on snow mold of winter wheat in Washington state. Plant Dis. Rep., 1953, 37: 354-359.

35. L o ve le s s A.R. Observations on the biology of clover rot. Ann. Appl. Biol., 1951, 38: 642-664.

36. Gould Ch.J., B ythe r R.S. Diseases of tulips. Washington State University Cooperative Extension. Extension Bull., 1979, 711.

37. M c Key H.C., Reade r J.M. Snow mold damage in Idaho's winter wheat. Idaho Agric. Exp. Stn. Bull., 1953, 200.

38. B rue hl G.W. Effect of plant size on resistance to snow mold of winter wheat. Plant Dis. Rep., 1967, 51: 815-819.

39. B rue hl G.W., C u n fer B.M. Physiologic and environmental factors that affect the severity of snow mold of wheat. Phytopathology, 1971, 61: $792-798$ (doi: 10.1094/Phyto-61-792).

40. S mith J.D., J a cks on N., Wool hou se A.R. Fungal diseases of amenity turf grasses. NY, 1989. 
41. N e ls o n E.B. Craft C.M. Suppression of Typhula blight with top-dressing amended with composts and organic fertilizers. Biol. Cult. Tests, 1992, 7: 107.

42. Huber D.M., M c K a y H.C. Effect of temperature, crop, and depth of burial on the survival of Typhula idahoensis sclerotia. Phytopathology, 1968, 58: 961-962.

43. Lawton M.B., B u rpe e L.L. Effect of rate and frequency of application of Typhula phacorrhiza on biological control of Typhula blight of creeping bentgrass. Phytopathology, 1990, 80: 70-73 (doi: 10.1094/Phyto-80-70).

44. S prague R. Wheat snow mold in Eastern Washington 1955 to 1956. Plant Dis. Rep., 1956, 40: $640-642$.

45. Olva ng H. Chemical control of winter damaging fungi in cereals. Norwegian J. Agric. Sci., 1992, 7: 55-61.

46. Polit y k o P.M. Zashchita rastenii, 1988, 12: 18.

47. Hoftu n H. Lagring av purre: I. Verknad av sortar og ved hausting. Meldinger fra Norges Landbrukshøgskole, 1978, 57: 1-26.

48. H a ege rmark U. Negra broddehandlingeförsök pe Hösten i hostvelte med benomyl och triadimefon. Växtskyddsnotiser, 1979, 43: 138-139.

49. Ebenebe C., Fehrman H. Evolution of a number of systemic fungicides for the control of Typhula incarnata in winter barley. PfIKrankh, 1974, 12: 711-716.

50. S m ith J.D., S ty nes B.A., M o ore K.J. Benomyl stimulated growth of a Basidiomicetes on turf. Plant Disease Reporter, 1970, 54: 774-775.

51. Hossfeld R. Förderung der Typhula - Fäule an Wintergerate durch Rinsatz von Fungiziden zur Halmbruchbekampfung. Nachrichtenblatt des Deutschen Pflanzenschutzdienstes, 1974, 26: 19.

52. C a veli e r M., M a ro qu in C. Interférence d'une epidemie provoquée pour la premiére foir en Belgique par Typhula incarnata Lasch ex Fr. et d'une recrudescence de la jaunisse nanisante de l'otge sur encourgeon. Caractéresation des symptoms at evaluation de leur incidence respective sur les rendements. Parasitica, 1978, 34: 277-295.

53. F r a n c is B.M. Toxic Substances in the Environment. NY, 1994.

54. V a rga s J.M. Management of Turfgrass diseases. CRC Press, Inc., Boca Raton, Florida, USA, 1994.

55. Fushte y S.G., Frank R. Distribution of mercury residues from the use of mercurial fungicides on golf course greens. Can. J. Soil Sci., 1981, 61: 525-527 (doi: 10.4141/cjss81-060).

56. Matthews S.L., McCracken I.R., Lonergau G. Mercury contamination of gold courses due to pesticide use. Bull. Environ. Contain. Toxicol., 1995, 55: 390-397.

57. Spisok pestitsidov $i$ agrokhimikatov, razreshennykh $k$ primeneniyu na territorii Rossiiskoi Federatsii (Prilozhenie $k$ zhurnalu "Zashchita $i$ karantin rastenii») [List of pesticides and agrochemicals allowed for use in the Russian Federation: Supplemented to the Protection and plant quarantine journal]. Zashchita i karantin rastenii, 2014, 4.

58. J a $\mathrm{m}$ a la i n e $\mathrm{n}$ E.A., F e $\mathrm{n}$ s te $\mathrm{r} \mathrm{m}$ a $\mathrm{c}$ he $\mathrm{r}$ J.M. Typhula blight, its cause, epidemiology and control. J. Sports Turf Res. Inst., 1969, 45: 6-73.

59. Fushte y S.G. Chemical control of snow mold in bentgrass turf in southern Ontario. Can. Plant. Dis. Surv., 1980, 60: 225-231.

60. Kalli o A. Chemical control of snow mold (Sclerotinia borealis) on four varieties of bluegrass (Poa pratensis) in Alaska. Plant Dis. Rep., 1966, 50: 69-72.

61. S a i t o I., T k a c h e $\mathrm{nk}$ o O.B. Low temperature species of Sclerotinia causing plant diseases in winter. Chapter 10. Advances in plant diseases management. Hung-Chang Huang, Surya N. Acharya (eds.). Research Singpost, Kerala, India, 2003: 195-214.

62. Serafinchon A. Snow mold, gray or speckled. Government of Alberta, 2001 (http://wwwl.agric.gov.ab.ca).

63. W at k in s J.E. Turfgrass fungicide trade names. Nebraska Cooperative Extension NF 95-214 (Revised June 1999) (http:// ianrpubs.unl.edu/plantdisease/nf214.htm).

64. L e vit i n M.M., T y u t e r e v S.L. Zashchita i karantin rastenii, 2003, 11: 2-46.

65. S e r a y a L.G. Vozbuditel' seroi (pyatnistoi) snezhnoi pleseni grib Typhula ishikariensis S. Imai: biologiya, ekologiya, patogenez $i$ obosnovanie priemov zashchity. Kandidatskaya dissertatsiya [Gray snow mold pathogen, Typhula ishikariensis S. Imai: biological features, pathogenesis, and defense. PhD Thesis]. Moscow, 2001.

66. S a rycheva L.M. Vliyanie regulyatorov rosta rastenii $i$ fungitsidov na patogenez infektsionnogo vypadeniya i urozhainost' ozimykh zernovykh kul'tur. Kandidatskaya dissertatsiya [Effect of growth stimulators and fungicides on pathogenesis of infectious lesion and yield in winter grain crops. PhD Thesis]. Moscow, 2010.

67. Kostenko E.S. Sovershenstvovanie priemov fitosanitarnogo monitoringa $i$ zashchity gazonnykh travostoev ot osnovnykh vrednykh organizmov (snezhnoi pleseni $i$ zhukov shchelkunov). Avtoreferat kandidatskoi dissertatsii [Improvement of phytosanitary monitoring and lawn herbage protection from main adverse organisms, the show mold and click beetles. PhD Thesis]. Moscow, 2012. 
68. Frank J.A., S anders P.L. ICIA5504: a novel, broad-spectrum, systemic turfgrass fungicide. British Crop Protection Conf. «Pests and Diseases». Brighton, U.K, 1994, 2: 871876.

69. Burpe e L.L. Interactions among low-temperature-tolerant fungi: Prelude to biological control. Can. J. Plant Pathol., 1994, 16: 247-250 (doi: 10.1080/07060669409500762).

70. M a t s u m ot o N. Biological control of snow mold. In: Plant cold hardiness /X.P. Li, T. Chen (eds.). Plenum, NY, 1998: 343-350.

71. Nels o n E.B., C raft C.M. Supression of Typhula blight with top-dressing amended with composts and organic fertilizers. Biol. Cult. Tests, 1992, 7: 107.

72. Boulter J.I., Boland G.J., Trevors J.T. Assessment of compost for suppression of Fusarium patch (Microdochium nivale) and Typhula Blight (Typhula ishikariensis) snow molds of turfgrass. Biological Control, 2002, 25: 162-172 (doi: 10.1016/S1049-9644(02)00060-9).

73. $\mathrm{Ne} 1 \mathrm{~s}$ o n E.B. Biological control of turfgrass diseases. Ext. Publ. Inf. Bull. Cornell University, Ithaca, NY, 1992, 220: 78-90.

74. Johansson P.M., Johnsson L., Gerhardson B. Suppression of wheat-seedling diseases caused by Fusarium culmorum and Microdochium nivale using bacterial seed treatment. Plant Pathol., 2003, 52: 219-227 (doi: 10.1046/j.1365-3059.2003.00815.x).

75. Levendorfs J.P., Eberhard T.H., Levendorfs J.J., Gerhardson B., $\mathrm{H}$ ö k e b e r g M. Biological control of snow mould (Microdochium nivale) in winter cereals by Pseudomonas brassicacearum, MA 250 . BioControl, 2008, 53(4): 651-665.

76. Kuzina E.V., Burkhanov F.F., Davshetshin T.K., Silishchev N.N., L o g i n o v O.N. Agrarnaya Rossiya, 2011, 2: 22-24.

77. H a rd e r P.R., T ro 11 J. Antagonism of Trichoderma spp. to sclerotia of Typhula incarnata. Plant Dis. Rep., 1973, 57: 924-926.

78. Matsu moto N., Taji mi A. Preliminary experiments for biological control of snow mold caused by Typhula incarnata and T. ishikariensis. Proc. XV Int. Grassland Congr. Kyoto, Japan, 1985: 787-788.

79. M atsu moto N., Taji mi A. Bacterial flora associated with the snow mold fungi, Typhula incarnata and T. ishikariensis. Ann. Phytopathol. Soc. Japan, 1987, 53: 250-253.

80. Hoshino T., Morita H., Fujiwara M., Higashiyama T., Tkachenko O.B., $\mathrm{S}$ a i to I., M atsu y a m H., Yu moto I. Heat resistant bio-control agents against snow molds (Typhula incarnata and T. ishikariensis) in various materials from several cold regions. Proc. Int. Symp. on identification and use of microbial resources for sustainable agriculture. National Agr. Res. Center for Kyushu Okinawa Region, 2004: 88-97.

81. Burpe e L.L., Kaye L.M., Goulty L.G., Lawton M.B. Suppression of gray snow mold on creeping bentgrass by an isolate of Typhula phacorrhiza. Plant Disease, 1987, 71: 97 100 (doi: 10.1094/PD-71-0097).

82. Lawton M.B., B u rpe e L.L. Effect of rate and frequency of application of Typhula phacorrhiza on biological control of Typhula blight of creeping bentgrass. Phytopathology, 1990, 80: 70-73 (doi: 10.1094/Phyto-80-70).

83. Lawton M.B., Burpe e L.L., Goulty L.G. Factors influencing the efficacy of a biofungicide control of control of gray snow mold on turfgrass. Proc. Br. Crop Prot. Conf., 1986, 1: 393-398.

84. Matsu moto N., Taji mi A. Biological control of Typhula ishikariensis on perennial ryegrass. Ann. Phytopath. Soc. Jpn., 1992, 58: $741-751$ (doi: 10.3186/jjphytopath.58.741).

85. Wu C., Hsiang T., Y a ng L., Li n L.X. Efficacy of Typhula phacorrhiza as a biocontrol agent of gray snow mould of creeping bentgrass. Can. J. Bot., 1998, 76(7): 1276-1281.

86. H si ang T., Wu C., Cook S. Residual efficacy of Typhula phacorrhiza as a biocontrol agent of grey snow mold on creeping bentgrass. Can. J. Plant Pathol., 1999, 21(4): 382-387 (doi: 10.1080/07060669909501175).

87. H s i a n g T. Diversity and management of snow mold diseases of grasses. Proc. of Int. Workshop «Plant-microbe interactions at low temperature under snow». Sapporo, 1997: 132-142.

88. H s i a n g T. Biological control of turfgrass snow molds. GreenMaster, 2000, 35(5): 12-15.

89. Wu C., Hsiang T., Y ang L., Li n L.X. Efficacy of Typhula phacorrhiza as a biocontrol agent of gray snow mould of creeping bentgrass. Can. J. Bot., 1998, 76(7): 1276-1281.

90. Wu C., H siang T. Mycelial growth, sclerotial production and carbon utilization of three Typhula species. Can. J. Bot., 1999, 77: 312-317 (doi: 10.1139/cjb-77-2-312).

91. S chn e id e r E.F., S e a m a n W.L. Typhula phacorrhiza on winter wheat. Can. J. Plant Pathol., 1986, 3: 269-276 (doi: 10.1080/07060668609501799).

92. S c h n e id e r E.F., S e a m e $\mathrm{n}$ W.L. Saprophytic behavior of three Typhula species on winter wheat substrates. Can. J. Plant Pathol., 1988, 10: 289-296 (doi: 10.1080/07060668809501702).

93. T a z i n a S.V. Obosnovanie zashchity ozimykh zernovykh kul'tur ot infektsionnogo vypadeniya rastenii. Kandidatskaya dissertatsiya [Basis for winter grain crop protection from infectious lesion. PhD Thesis]. Moscow, 2005. 
94. Matsumoto N., Tkachenko O.B., Hoshino T. The pathogenic species of Typhula. In: Low temperature plant microbe interactions under snow. Sapporo, Hokkaido National Agr. Exp. Station, 2001: 49-59.

95. Wo n g P.T.W., M c B e ath J.H. Plant protection by cold-adapted fungi. In: Biotechnological applications of cold-adapted organisms. R. Margesin, R. Schinner (eds.). Heidelberg, Germany, 1999: 177.

96. Sheng M., Gay P.A., M c B e ath J.H. Determination of chitinolitic activity in under differing environmental conditions. In: Proceedings of biocontrol in new millenium: building for the future on past experience. D.M. Huber (ed.). Purdue University Press, West Lafayette, 2001: 57-62.

97. M c B e a th J.H. Snow mold-plant-antagonist interactions: survival of the fittest under the snow. American Phytopathological Society press, The Plant Health Instructor, 2002 (doi: 10.1094/PHI-I-2002-1010-01).

98. G a ud et D.A., La r o c he A. Snow mold-crop-environment interactions. In: Biotechnological applications of cold-adapted organisms. R. Margesin, F. Schinner (eds.). Springer Berlin Heidelberg, 1999: 191-202 (doi: 10.1007/978-3-642-58607-1_13).

99. S m it h J.D., D a vid s o n J.G.N. Acremonium boreale n. sp., a sclerotial, low-temperaturetolerant, snow mold antagonist. Can. J. Bot., 1979, 57: 2122-2139 (doi: 10.1139/b79-265).

100. S m it h J.D., Goss e n B.D. Interaction of Coprinus psychromorbidus, Acremonium boreale and an unidentified low-temperature pathogen of bentgrass turf. Proc. 10 th Ann. Plant Pathol. Soc. Alberta, Brooks, AB, Canada, 1989.

101. Shchukovskaya A.G., Tkachenko O.B., Shesteperov A.A. Mikogel'minty ozimoi pshenitsy - potentsial'nye bioagenty griba Microdochium nivale. Materialy konferentsii "Teoriya i praktika bor'by s parazitarnymi boleznyami» [Proc. Conf. «Theoretical and practical bases for defense against parasitic diseases»]. Moscow, 2012, Issue 13: 466-468.

102. Sh chukovskay a A.G., Tk achenko O.B., Shesteperov A.A. Materialy Mezhdunarodnoi nauchnoi konferentsii «Sovremennye problemy obshchei parazitologii» [Proc. Int. Conf. «Current problems in general parasitology». Moscow, 2012: 397-401]. Moscow, 2012: 397-401.

103. Shchukovsk y a A.G. Materialy Mezhdunarodnoi nauchnoi konferentsii «Sovremennye problemy obshchei parazitologii» [Proc. Int. Conf. «Current problems in general parasitology»]. Moscow, 2012: 401-404.

104. Shchukovskaya A.G., Tkachenko O.B., Shesteperov A.A. Materialy 10-go Mezhdunarodnogo nematologicheskogo simpoziuma [Proc. 10 $0^{\text {th }}$ Int. Symp. on nematodes]. Bol'shie Vyazemy, 2013: 83-85.

105. T k a c h e n k o O.B. Sel'skokhozyaistvennaya Biologiya [Agricultural Biology], 2003, 3: 101-108.

106. Bruehl G.W., Sprague R., Fischer W.R., Nagamitu M., N e lso n W.L., Vog e 1 O.A. Snow molds of winter wheat in Washington. Washington Agric. Exp. Stn. Bull., 1966, 677: 1-21.

107. Sunderman D.W. Modifications of the Cormack and Lebeau technique for inoculating winter wheat with snow mold-causing Typhula species. Plant Dis. Rep., 1964, 48: 394-396.

108. $\mathrm{Nakaji} \mathrm{m} \mathrm{a} \mathrm{T.,} \mathrm{A} \mathrm{b} \mathrm{e} \mathrm{J.} \mathrm{A} \mathrm{method} \mathrm{for} \mathrm{assessing} \mathrm{resistance} \mathrm{to} \mathrm{snow} \mathrm{molds} \mathrm{Typhula} \mathrm{incarnata}$ and Microdochium nivale in winter wheat incubated at the optimum growth temperature ranges of the fungi. Can. J. Bot., 1990, 68: 343-346 (doi: 10.1139/b90-045).

109. O v s y a n k in a A.V. Struktura populyatsii vozbuditelei kornevoi gnili i snezhnoi pleseni ozimoi rzhi $i$ otbor iskhodnogo materiala dlya selektsii ustoichivykh sortov. Kandidatskaya dissertatsiya [Structure of the populations of winter rye root rot and snow mold pathogens and selection of parental forms in breeding for resistance. PhD Thesis.]. Moscow, 2000.

110. Iriki N., Kawskami A., Nakajima T. et al. Field resistance of winter wheat to Typhula ishikariensis and Microdochium nivale. Abstracts of NJF seminar no 311 «Plant and microbe adaptation to winter environments in northern areas». Akureyri, Iceland, 2000: 23-24.

111. Iriki N., Kuwabara T., Takata K., Yoshida M., Kawakami A. Physiological and quality traits of Aegilops cylindrica accession screened for snow mold resistance. Proc. $9^{\text {th }}$ Int. Wheat Genetic Symp. Saskatoon, Saskatchewan, Canada, 1998, V. 5: 37-38.

112. Eiges N.S., Kuznetsova N.L., Volchenko G.A., Artamonov V.D., Va isfel'd L.I., Dolgova S.P., Kakhrimanova N.N., Volchenko S.G. Visnyk Ukrainskogo tovarystva genetykiv i selektsioneriv, 2009, 7(2): 269-275.

113. Eiges N.S., Volchenko G.A., Vaisfel'd L.I., Volchenko S.G. Materiali $V$ Vseukraïnskoi naukovo-praktichnoi konferentsii molodikh uchenikh «Ekologichni problemi sil'skogospodarskogo virobnitstva» [Proc. V Ukrainian Conf. «Ecological problems in agriculture»]. Yaremche, 2011: 28-29.

114. S m it h J.D., C o o ke D.A. Dormie Kentucky bluegrass. Can J. Plant Sci., 1978, 58: 291-292. 